\title{
Content validation of an educational booklet for asthma control and management in children
}

\author{
Validação de conteúdo de cartilha educativa para controle e manejo da asma em crianças \\ Validación del contenido del folleto educativo para el control y manejo del asma en niños
}

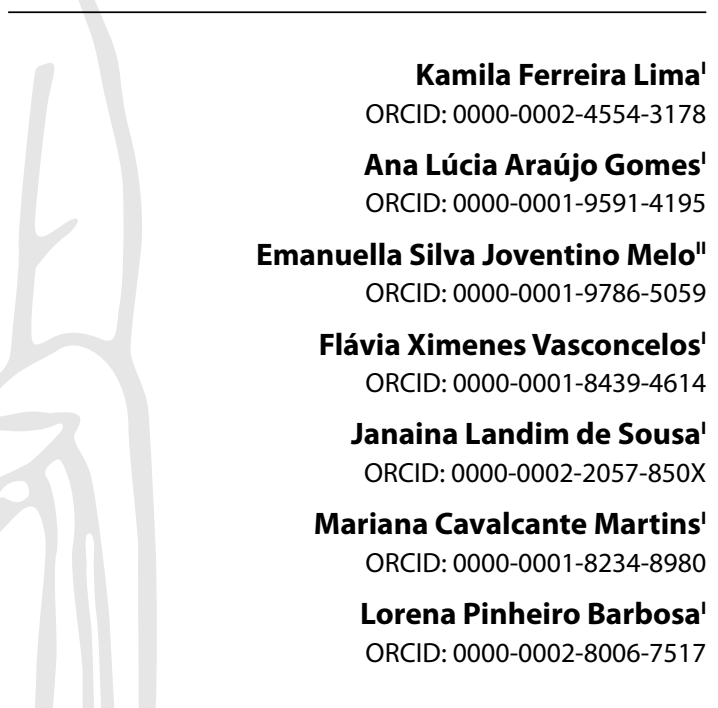

'Universidade Federal do Ceará. Fortaleza, Ceará, Brazil. "Universidade da Integração Internacional da Lusofonia Afro-brasileira. Redenção, Ceará, Brazil.

How to cite this article:

Lima KF, Gomes ALA, Melo ESJ, Vasconcelos FX, Sousa JL,

Martins MC, et al. Content validation of an educational booklet for asthma control and management in children. Rev Bras Enferm. 2021;74(Suppl 5):e20200353. https://doi.org/10.1590/0034-7167-2020-0353

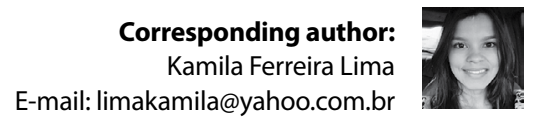

EDITOR IN CHIEF: Antonio José de Almeida Filho ASSOCIATE EDITOR: Marcos Brandão

Submission: 04-26-2020

Approval: 01-25-2021

\section{ABSTRACT}

Objective: to validate the content and appearance of the educational booklet "You can control your child's asthma - let's learn together?" with parents and caregivers of children with asthma. Methods: this is a methodological study, carried out with 34 mothers and caregivers of children, from two to 10 years old, diagnosed with asthma. The educational booklet validation was performed using Content Validity Index (CVI) and assessment of comprehension, attractiveness, self-efficacy, persuasion, and cultural acceptance domains. Results: the booklet was considered clear (99.8\%) and relevant (100\%), with a global CVI of 0.99. Domain assessment proved to be an easy-to-understand tool, culturally appropriate, attractive, with persuasive power and promoting self-efficacy. Conclusion: the booklet is valid and adequate for promoting the self-efficacy of parents and caregivers in childhood asthma control and management, potentially scalable to other realities of outpatient care. Descriptors: Asthma; Self Efficacy;Validation Study; Educational Technology; Health Promotion

\section{RESUMO}

Objetivo: validar o conteúdo e a aparência da cartilha educativa "Você é capaz de controlar a asma da sua criança - vamos aprender juntos?" junto a pais e cuidadores de crianças com asma. Métodos: estudo metodológico, realizado com 34 mães e cuidadoras de crianças, de dois a 10 anos de idade, com diagnóstico de asma. A validação da cartilha educativa foi realizada a partir do Índice de Validade de Conteúdo (IVC) e da avaliação dos domínios compreensão, atratividade, autoeficácia, persuasão e aceitação cultural. Resultados: a cartilha foi considerada clara $(99,8 \%)$ e relevante $(100 \%)$, com IVC global de 0,99 . A avaliação dos domínios evidenciou ser uma ferramenta de fácil compreensão, adequada culturalmente, atrativa, com poder de persuasão e de promover autoeficácia. Conclusão: a cartilha é válida e adequada para promoção da autoeficácia de pais e cuidadores no controle e manejo da asma infantil, potencialmente escalável a outras realidades de atendimento ambulatorial. Descritores: Asma; Autoeficácia; Estudo de Validação; Tecnologia Educacional; Promoção da Saúde.

\section{RESUMEN}

Objetivo: validar el contenido y la apariencia del folleto educativo "Puedes controlar el asma de tu hijo, ¿vamos a aprender juntos?" con los padres y cuidadores de niños con asma. Métodos: estudio metodológico, realizado con 34 madres y cuidadoras de niños, de 2 a 10 años, diagnosticados de asma. La validación del cuadernillo educativo se realizó mediante el Índice de Validez de Contenido (IVC) y la evaluación de los dominios comprensión, atractivo, autoeficacia, persuasión y aceptación cultural. Resultados: el folleto se consideró claro $(99,8 \%)$ y relevante $(100 \%)$, con un IVC global de 0,99 . La evaluación de los dominios resultó ser una herramienta fácil de entender, culturalmente apropiada, atractiva, con el poder de persuadir y promover la autoeficacia. Conclusión: el folleto es válido y adecuado para promover la autoeficacia de los padres y cuidadores en el control y manejo del asma infantil, potencialmente escalable a otras realidades de la atención ambulatoria.

Descriptores: Asma; Autoeficacia; Estudio de Validación; Tecnología Educacional; Promoción de la Salud. 


\section{INTRODUCTION}

Asthma is a chronic respiratory disease that globally affects more than $\mathbf{3 0 0}$ million people, from childhood to adulthood, with increasing prevalence and morbidity in developing countries ${ }^{(1)}$.

In Brazil, a study based on data extracted from the Department of Informatics of the Unified Health System (DATASUS - Departamento de Informática do Sistema Único de Saúde) found 120,000 annual hospitalizations for asthma. Between 2008 and 2013, there was a reduction of $10 \%$ and $36 \%$ in the absolute number of deaths and hospitalizations due to asthma, respectively; however, the mortality rate in hospitalized patients increased by approximately $25 \%{ }^{(2)}$. Deaths by asthma are considered relatively rare, however of great importance, because they are, in most cases, preventable through early diagnosis and appropriate treatment ${ }^{(1)}$.

In the context of children's health, asthma remains the chronic respiratory disease with the highest prevalence and impact on childhood. Achieving and maintaining control requires continuous treatment, with a broad and multidisciplinary approach, including health education interventions targeted at children and families ${ }^{(3)}$, because the knowledge and attitude of parents and caregivers in relation to childhood asthma control and management effectively influence good management, with a consequent reduction in morbidity and mortality ${ }^{(4)}$. However, it is known that only access to adequate information does not guarantee the promotion of children's health, and it is also necessary that parents and caregivers have self-efficacy to feel able to incorporate appropriate practices in their daily lives ${ }^{(5)}$.

Self-efficacy is related to individuals' belief regarding their own abilities to successfully perform an intended action ${ }^{(6)}$, which may influence the decision to adopt behaviors, the effort that will be employed in carrying out actions that result in effective management of asthma and other chronic diseases and how long it will persist in the face of obstacles that may arise ${ }^{(6-7)}$. Moreover, high levels of self-efficacy can improve therapeutic adherence, lead to better clinical results, reduce aggravation processes and generate short, medium and long-term benefits for the patient, family and health system, even in the face of adverse conditions ${ }^{(8)}$.

When considering that the use of technological resources contributes to the success of health education, the feasibility of using an educational booklet is highlighted, as it is an instrument that can reinforce verbal guidelines, serve as a guide at home, for instance, in case doubts and difficulties in handling. It should be noted that, searching national and international literature, through the Brazilian Library of Dissertations and Theses (BDTD - Biblioteca Brasileira de Dissertações e Teses) and the PubMed, Scopus, CINAHL, EMBASE and Cuiden databases, no educational booklet identified based on self-efficacy for childhood asthma control and management. Thus, the booklet entitled "You can control your child's asthma - let's learn together?"(9) was designed and validated by judges, aiming at helping parents and caregivers of children with asthma to promote self-efficacy in childhood asthma control and management.

Therefore, it was considered relevant to validate the educational technology, with parents and caregivers of children with asthma, to verify their suggestions so that the material was as close as possible to their realities, with clear and understandable language so that the technology could be able to meet its needs; after all, all educational material needs to be accessible and attractive to the target audience, being, therefore, essential that it be submitted to such assessment ${ }^{(10)}$.

\section{OBJECTIVE}

To validate the content and appearance of the educational booklet "You can control your child's asthma - let's learn together?" with parents and caregivers of children with asthma.

\section{METHODS}

\section{Ethical aspects}

The study was approved by the Research Ethics Committee of Universidade Federal do Ceará (UFC), according to Opinion 1.846 .995 , following the ethical principles of research involving human beings, according to Resolution 466/2012 ${ }^{(11)}$.

\section{Study design, place, and period}

This is a methodological study, with content validation and appearance of the educational booklet entitled "You can control your child's asthma - let's learn together?", Developed from June to August 2018 in a Primary Health Care Unit (PHCU), which has regular care and a greater number of children registered in the Comprehensive Care Program for Children and Adults with Asthma (PROAICA - Programa de Atenção Integral à Criança e Adulto com Asma) in the city of Fortaleza, Ceará, Brazil.

\section{Population or sample, inclusion and exclusion criteria}

The sample size was defined by convenience, respecting the recommendations of authors who advise a number of 25 to 50 subjects for the validation of technologies/instruments ${ }^{(12)}$. Thus, 34 parents and caregivers of children with asthma participated in the study, without any refusal from those who were invited and who met the selection criteria.

Inclusion criteria were being a father and/or caregiver of a child between two and 10 years old, with a medical diagnosis of asthma, registered in PROAICA. The classification of children according to the World Health Organization (WHO) was adopted. Adults who do not know how to read, with a medical diagnosis related to cognitive impairment that would make communication impossible, reading the booklet and responding to the instrument were excluded.

\section{Study protocol}

The booklet was built according to the recommendations for the design of educational materials $s^{(10,13)}$ and the practical guides Simply Put ${ }^{(14)}$, Guide to Creating and Evaluating Patient Materials $^{(15)}$ and Federal Plain Language Guidelines ${ }^{(16)}$, aiming to promote the self-efficacy of parents and caregivers for childhood asthma control and management.

Technology addressed the themes: asthma definition; symptomatology; prevention of triggers that trigger symptoms or exacerbate crises; importance of health services for asthma 
control; indication of the use of medications; crisis management at home and need to seek emergency services; use of inhaled medication; care to prevent adverse events, such as oral hygiene; expectations of results for achieving and maintaining asthma control and improving quality of life.

The booklet's content was based on the Self-Efficacy and Their Child's Level of Asthma Control Scale, Brazilian version ${ }^{(7)}$, on Theory of Self-efficacy ${ }^{(6)}$ and on clinical guidelines regarding asthma control parameters ${ }^{(17-19)}$.

The technology was previously validated by content judges (with teaching and assistance experience) and technical judges (with experience in design, communication and education), which presented a global Content Validity Index (CVI), with regard to relevance theoretical, 0.93 by both content judges and technicians. The final version was completed with 40 pages, containing cover, pre- and post-textual elements. The last pages were dedicated to a review so that parents and caregivers could exercise and establish essential points for an effective asthma management, record consultations and complications and use an illustrated action plan that can be completed by health professionals together with those responsible for child care ${ }^{(9)}$.

Data collection took place in two stages. In the first stage, parents and caregivers who were waiting for the routine consultation of PROAICA at PHCU and agreed to participate in the research were invited to go to a private room and start reading the booklet individually, with an average duration of 15 minutes. The researcher was present at this moment to answer any questions that might arise.

The second stage took place sequentially, consisting of the application of the Doak, Doak and Root adapted questionnaire ${ }^{(10)}$, composed of three parts: 1) sociodemographic characterization; 2) domain assessment: attractiveness, related to the way of displaying the information; self-efficacy, referring to the ability to develop confidence to perform the care proposed in the booklet; cultural acceptability, which concerns adequacy of educational material to the reality of the target population; persuasion, which concerns a healthy behavior promotion; understanding, through aid of images; 3 ) Individual assessment of each booklet page, through a checklist, which allowed the assessment of clarity and relevance with two answer options, yes or no, and the degree of relevance, which was investigated using a Likert-type scale, with four answer options: (1) irrelevant, (2) not relevant, (3) really relevant, and (4) very relevant. Moreover, there was a space for participants to make observations and suggestions for each page of the booklet.

Data analysis was performed in the Statistical Package for the Social Sciences (SPSS, version 20, license 10101131007). The value of CVI for each page and, later, of the complete material, was calculated from relevance classification, which varied from -1 to +1 . The item with agreement among participants equal to or greater than $0.8^{(20)}$ was considered valid. A score of +1 was assigned to pages with relevance rating 3 or 4 according to the Likert scale used ${ }^{(21)}$. The global CVI analysis was performed based on the average CVI assigned to each page. To calculate the $95 \%$ confidence interval $(\mathrm{Cl})$, the binomial distribution was used, so that $p$ value $>0.8$ confirms the adequacy of the educational material prepared.
The participants' response regarding clarity and relevance was used to validate appearance, considering agreement equal to or greater than $75 \%{ }^{(22)}$. Understanding, attractiveness, self-efficacy, cultural acceptability and persuasion were organized in absolute values and percentage, which are presented in a descriptive way and discussed according to literature.

\section{RESULTS}

Thirty-four fathers and caregivers were part of the validation of the booklet's second version, all female, being 25 mothers, 06 grandparents and 03 aunts aged between 18 and 60 years (average of 34.6 years). The participants were from Fortaleza, $22(64.7 \%)$ finished high school, with an average study time of 9.5 years. Most performed household activities $(n=21,61.7 \%)$ and lived with a partner $(n=23,67.6 \%)$. The average number of family members was 4.1 people, and the family income ranged from $\mathrm{R} \$ 300.00$ (about 54.5 US dollars) to $\mathrm{R} \$ 3,500.00$ (about 636 US dollars), with an average of R\$1,113.00 (about 202 US dollars).

Assessment of the clarity of each page showed agreement between the participants from $97 \%$ to $100 \%$, with an average of $99.8 \%$. The pages referring to "Presentation" and "Concept of asthma triggers and how to recognize them" were assessed with 97\% agreement. The others obtained an excellent assessment, reaching $100 \%$ agreement. Relevance was another aspect assessed that obtained excellent concordance index for reaching $100 \%$ on all pages.

From the classification of relevance attributed to each page, individual CVI was calculated, which ranged from 0.97 to 1.00. The pages that present the subjects "Main asthma triggers" and "Care with changes in the weather and exposure to cigarette smoke" obtained CVI of 0.97 , and all other pages, CVI equal to 1.0. The material presented a global CVI of 0.99 , higher than the established limit of 0.8 , necessary to consider the material as valid and adequate, indicating a high level of agreement among participants (Table 1).

Regarding the domains of understanding, attractiveness, cultural acceptability and persuasion, the participants, in total $(n=34,100 \%)$, assessed the technology positively. They reported understanding the content and demonstrated having absorbed the knowledge related to asthma by being able to verbally reproduce information presented throughout the booklet. Good attractiveness was perceived by the interest in completing the material reading, which was also reinforced by verbal report. Cultural acceptability was confirmed by verbalization of parents and caregivers about the recognition of their own reality in scenes or images present in the booklet. They were predisposed to perform activities described in the material that would help in asthma control and management, expressing the booklet's persuasive power.

In the self-efficacy domain, most mothers and caregivers $(n=32,94.1 \%)$ claim to believe they are able to follow what the booklet proposes and consider that the booklet has the necessary information to make them feel confident in controlling childhood asthma ( $n=33,97.0 \%)$ (Table 2$)$.

The subjects in the booklet considered essential for childhood asthma control and management, according to mothers 
and caregivers participating in the study, were factors that can trigger or exacerbate asthma symptoms (triggers) ( $n=23,67.6 \%)$, prevention triggers $(n=22,64.7 \%)$, recognition of the need to use medication $(n=18,52.9 \%)$ and instructions on inhalation $(n=12$, $35.3 \%)$ (Figure 1). Still, $91.2 \%(n=31)$ stated that there is no need for additional information in the booklet.
Only three participants ( $\mathrm{N}=3,8.8 \%)$ suggested changes or additions to the booklet, namely: information on first aid in cases of severe crisis; exposure of content on dye allergy as a trigger for crisis exacerbation; advice on keeping your child always dressed for the cold. However, these suggestions were not accepted because they are not part of the scope of the booklet.

Table 1 - Agreement of mothers and caregivers regarding the relevance of the content covered on each page of the booklet, Fortaleza, Ceará, Brazil, 2018

\begin{tabular}{|c|c|c|c|c|c|}
\hline Pages/Subjects & $\mathbf{n}^{\circ}$ & $\%$ & $C V I^{*}$ & $95 \% \mathrm{Cl} * *$ & $p$ \\
\hline Cover & 34 & 100 & 1 & $0.89-1.00$ & 1 \\
\hline Presentation & 34 & 100 & 1 & $0.89-1.00$ & 1 \\
\hline Presentation of the characters and context of the story & 34 & 100 & 1 & $0.89-1.00$ & 1 \\
\hline Asthma concept & 34 & 100 & 1 & $0.89-1.00$ & 1 \\
\hline Main symptoms of asthma & 34 & 100 & 1 & $0.89-1.00$ & 1 \\
\hline Concept of asthma triggers and how to recognize them & 34 & 100 & 1 & $0.89-1.00$ & 1 \\
\hline Main asthma triggers & 33 & 97.05 & 0.97 & $0.84-0.99$ & 0.99 \\
\hline Recommendations for reducing triggers & 34 & 100 & 1 & $0.89-1.00$ & 1 \\
\hline Home care & 34 & 100 & 1 & $0.89-1.00$ & 1 \\
\hline Care of clothes, pollen, and animals & 34 & 100 & 1 & $0.89-1.00$ & 1 \\
\hline Care about changes in the weather and exposure to cigarette smoke & 33 & 97.05 & 0.97 & $0.84-0.99$ & 0.99 \\
\hline Garbage care & 34 & 100 & 1 & $0.89-1.00$ & 1 \\
\hline Reinforcement of self-efficacy regarding the prevention of triggers & 34 & 100 & 1 & $0.89-1.00$ & 1 \\
\hline Importance of health services & 34 & 100 & 1 & $0.89-1.00$ & 1 \\
\hline Importance of vaccination & 34 & 100 & 1 & $0.89-1.00$ & 1 \\
\hline Recognition of the need to use medication & 34 & 100 & 1 & $0.89-1.00$ & 1 \\
\hline Action plan & 34 & 100 & 1 & $0.89-1.00$ & 1 \\
\hline Recognition of the need to take children to an emergency care & 34 & 100 & 1 & $0.89-1.00$ & 1 \\
\hline Inhaler use & 34 & 100 & 1 & $0.89-1.00$ & 1 \\
\hline Instructions for using inhalers with spacers and masks (Part I) & 34 & 100 & 1 & $0.89-1.00$ & 1 \\
\hline Instructions for using inhalers with spacers and masks (Part II) & 34 & 100 & 1 & $0.89-1.00$ & 1 \\
\hline Instructions for using inhalers with spacers only (Part I) & 34 & 100 & 1 & $0.89-1.00$ & 1 \\
\hline Instructions for using inhalers with spacers only (Part II) & 34 & 100 & 1 & $0.89-1.00$ & 1 \\
\hline Care of oral hygiene after using medication & 34 & 100 & 1 & $0.89-1.00$ & 1 \\
\hline Oral hygiene instructions & 34 & 100 & 1 & $0.89-1.00$ & 1 \\
\hline Expected outcome: controlled asthma & 34 & 100 & 1 & $0.89-1.00$ & 1 \\
\hline Result expectation: practice of physical activities & 34 & 100 & 1 & $0.89-1.00$ & 1 \\
\hline Expected outcome: school attendance and good sleep & 34 & 100 & 1 & $0.89-1.00$ & 1 \\
\hline Result expectation: improved quality of life & 34 & 100 & 1 & $0.89-1.00$ & 1 \\
\hline Checklist for asthma control & 34 & 100 & 1 & $0.89-1.00$ & 1 \\
\hline Child consultation records & 34 & 100 & 1 & $0.89-1.00$ & 1 \\
\hline Medication records & 34 & 100 & 1 & $0.89-1.00$ & 1 \\
\hline Action plan follow-up record & 34 & 100 & 1 & $0.89-1.00$ & 1 \\
\hline Record of complications & 34 & 100 & 1 & $0.89-1.00$ & 1 \\
\hline Total & & & 0.99 & & \\
\hline
\end{tabular}

Note: $n=34 ;{ }^{*}$ Content Validity Index; ${ }^{* *} 95 \%$ Confidence Interval based on binomial test.

Table 2 - Description of the responses of mothers and caregivers in the self-efficacy domain and of subjects cited as essential for asthma control, Fortaleza, Ceará, Brazil, 2018

Assessment of mothers and caregivers about self-efficacy beliefs in the booklet

Belief in the ability to follow what the booklet demonstrates

They consider that the booklet presents the necessary information to make them feel confident in controlling their children's asthma

Believes that the presence of a health professional is necessary to present and/or explain the booklet so that they feel confident in following the 0 information

Essential issues present in the booklet cited by mothers and caregivers for childhood asthma control and management

Factors that can trigger or exacerbate asthma symptoms (triggers)

Trigger prevention

Recognition of the need to use medication

Oral hygiene after using inhaled corticosteroids

Outcome expectations for controlled childhood asthma 

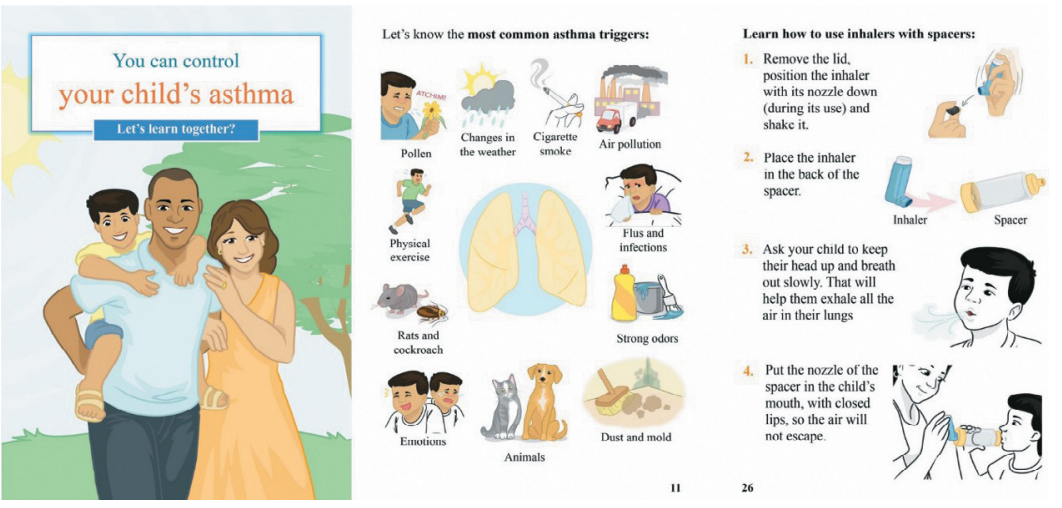

Figure 1 - Cover and content illustration of "You can control your child's asthma - let's learn together?"

\section{DISCUSSION}

Researches carried out in northeastern Brazil to validate the Self-Efficacy and Their Child's Level of Asthma Control Scale showed sociodemographic profiles of parents and caregivers of children with asthma similar to those of this study. The main similarities referred to participants'low educational level, low family income, occupation, and $\operatorname{sex}^{(7-8)}$. These characteristics reflect a reflection of part of the Brazilian population, with disadvantaged economic and educational conditions. The booklet validation in this scenario conditions the assumption that educational technologies with content and appearance that are clear and understandable by this stratum of the population are also adequate for people with better economic and educational conditions.

Validation with the target population has been carried out in the process of preparing educational materials. Validation makes it possible to verify that ideas are being transmitted in a clear, objective and appropriate way for the application of material in daily life, ensuring effective understanding and avoiding dubious interpretations that motivate inappropriate actions by those who use technology ${ }^{(5,23)}$.

In this process, participants are also encouraged to make suggestions about the material's content. The first recommendation given by the mothers and caregivers participating in the study referred to the addition of guidelines for carrying out first aid at home, in the case of a severe acute crisis. However, in the topic of the educational booklet entitled "Know when the asthma crisis needs to be treated in an emergency care", signs of seriousness are presented; it was emphasized that, in cases where the signs persist, even after the target population has followed all the action plan guidelines prescribed by the doctor, the health service should be sought immediately. Thus, it is considered that care beyond those described in the booklet requires knowledge, skills, materials, instruments that are commonly not available at home, such as intubation and ventilation, use of tools and equipment (pulse oximeter), intravenous medications, due to this, were not accepted ${ }^{(1)}$.

Another suggestion was in relation to the insertion of information about foods with dyes as a factor that can trigger symptoms or exacerbate crises. However, this has not been accepted, because, although it is established that acute exacerbations of asthma symptoms can be caused by allergens and irritants, such as mites, animal hair, pest excrement, such as cockroach, among others ${ }^{(1)}$, in the In the case of food, it is known that there is a strong association between food allergy and asthma, but this interaction is still under investigation ${ }^{(24)}$ and is rarely a trigger for triggering symptoms, even though it is considered a risk factor for mortality $^{(1)}$. A cross-sectional study, conducted in the Netherlands, with children and adolescents with asthma, when analyzing the disease control predictors associated with atopic comorbidities, including food allergy, allergic rhinitis and atopic dermatitis, found no association with uncontrolled asthma ${ }^{(25)}$.

The third suggestion was related to the addition of guidelines on how to keep the child protected from the cold with clothing. Changes in the weather are known to trigger or exacerbate asthma symptoms ${ }^{(26)}$. However, this recommendation was not accepted, because in Brazil, there is an intense climatic diversity, with cities with very high temperatures and others much colder so that, as the booklet was built to be applicable throughout the country, such recommendation could exclude certain climatic realities. Thus, it was decided to approach this theme emphasizing the need for special care, such as avoiding exposure of children to extreme temperatures, considering that other climatic associations and environmental conditions, such as storms, low humidity, high levels of air pollution are the cause of exacerbation or onset of asthma symptoms in children ${ }^{(1)}$.

In addition to content and appearance validation, it was considered necessary to assess the aforementioned domains, as the inclusion of these properties in the assessment process allows to verify the adequacy of health instructions for the target population $^{(10,23)}$. In the self-efficacy domain, the participants reported feeling able to follow the guidelines and care proposed in the booklet; it was suggested that reading the material enables the development of motivation and confidence to successfully undertake actions or behaviors that can improve health ${ }^{(10)}$, promoting the self-efficacy of parents and caregivers for asthma management and control.

A cross-sectional study, conducted in southeastern Spain, analyzed the association between the quality of life of children with asthma and their caregivers, with self-efficacy in managing the disease, finding that high levels of self-efficacy are associated with better quality of life for children and relatives. Moreover, it concluded that parental self-efficacy impacts asthma morbidity indicators $^{(27)}$.

Regarding the booklet's content, the subjects highlighted by the target population are really considered essential for asthma control, as ratified by national(18) and international guidelines ${ }^{(1)}$. Trigger prevention/control is among these issues. An intervention study, carried out in the United States, carried out an educational activity to control triggers in the homes of 41 families of children who had the highest number of hospitalizations related to asthma, showing improvement in children's sleep pattern, reduction in the use of rescue medication, improvement in the stress levels of children and their caregivers and decrease in hospital visits ${ }^{(28)}$. 
Another subject considered essential by the participants was how to recognize the need for the use of medication to relieve or rescue the crisis by children. It should be noted that the booklet includes the main signs of exacerbation of asthma symptoms and the individual action plan as a key instrument to recognize levels of control and acute exacerbations of asthma.

An experimental study, carried out in New York, USA, found that the use of low-level health literacy action plans, designed to guide caregivers of children with persistent asthma, helped health professionals to use clearer principles of communication than those who used the standard plan; in addition, they highlighted key aspects, such as knowing how to recognize the symptoms for the use of rescue medication, making continuous use of controlled medication and adherence to spacer use ${ }^{(29)}$.

Inhalation was also highlighted as essential, corroborating scientific evidence that states that the proper use of inhaled medications requires correct handling of inhalers coupled to spacers. The absence of this handling is the main cause of the lack of success in controlling the disease, being associated with more visits to the emergency service ${ }^{(30)}$. In view of this, the educational booklet presents a step by step of how to use inhalers coupled to spacers and inhalers coupled to spacers and masks. Additionally, it highlights that when there is no spacer, caregivers can request guidance from a health professional to build a handmade spacer, considering that its effectiveness has already been proven ${ }^{(31)}$.

Printed health technologies, such as booklet, can modify daily habits, as long as they present clear information, satisfy the needs of parents and caregivers of children with asthma and show the benefits of following the care addressed ${ }^{(32)}$. Therefore, the validation step is necessary so that the target population, when following the proposed guidelines, can achieve positive results with regard to health promotion ${ }^{(33)}$, especially for children with asthma.

\section{Study limitations}

The study carried out presented limitations regarding data collection, since a minimum time for asthma diagnosis for inclusion in the sample was not established. Furthermore, it took place in only one Brazilian Primary Health Care Unit, which may be restricted to the cultural issue of individuals from other locations in the country. It should also be noted that the educational booklet did not address dry powder inhalers.

\section{Contributions to nursing}

The use of "You can controlyour child's asthma-let's learn together?" can assist health professionals, especially nurses, in carrying out educational interventions to promote self-efficacy in childhood asthma control and management. In addition to serving as support to reinforce the guidance of professionals to parents and caregivers of children with asthma at home, as it is a technology that is easy to understand, it requires few resources for its use and already comes with a place to register an individualized care plan a every child. Furthermore, the study awakens that, given the relevance of asthma at the national and global levels, it is a theme that must be addressed in depth in nursing education as well as signaling the relevance of specific public policies for the public living with this disease.

\section{CONCLUSION}

"You can control your child's asthma - let's learn together?" was considered an instrument with valid content and adequate appearance, endorsing its use in promoting the self-efficacy of parents and caregivers in childhood asthma control and management.

Validation with the target population showed a global CVI equal to 0.99 , which indicates an excellent level of agreement between the participants. Furthermore, it was a fundamental step to avoid inaccurate results in terms of understanding, persuasion, attractiveness, self-efficacy, and cultural acceptance. The assessment carried out indicated increased motivation and confidence to adopt behaviors that educational technology proposes.

The booklet validated here is potentially scalable to other realities of outpatient care for children with asthma and in teaching, research and extension settings. As it is a brief and easy-to-read instrument, it is suggested to be disseminated for use by health professionals and managers of the Unified Health System (Sistema Único de Saúde), at local, regional and national level, aiming at wide use so that, associated with other measures assistance, may have a positive impact on the parameters of childhood asthma control.

\section{FUNDING}

This study was financed by Brazilian National Council for Scientific and Technological Development (CNPq - Conselho Nacional de Desenvolvimento Científico e Tecnológico).

\section{REFERENCES}

1. Global Initiative For Asthma (GINA). Global Strategy for Asthma Management and Prevention (2020 update) [Internet]. 2020 [cited 2020 Mar 17]. Available from: http://www. ginaasthma.com

2. Cardoso TA, Roncada C, Silva ER, Pinto LA, Jones MH, Stein RT, et al. The impact of asthma in Brazil: a longitudinal analysis of data from a Brazilian national database system. J Bras Pneumol. 2017;43(3):163-8. https://doi.org/10.1590/s1806-37562016000000352

3. Swartz MK, Meadows-Oliver M. Clinical outcomes of a pediatric asthma outreach program. J Nurse Pract. 2019;15(6):e119-e121. https://doi. org/10.1016/j.nurpra.2019.01.012

4. Lio M, Hamaguchi M, Narita M, Takenaka K, Ohya Y. Tailored education to increase self-efficacy for caregivers of children with asthma: a randomized controlled trial. Comput Inform Nurs. 2017;35(1):36-44. https://doi.org/10.1097/CIN.0000000000000295

5. Joventino ES, Ximenes LB, Penha JC, Andrade LCO, Almeida PC. The use of educational video to promote maternal self-efficacy in preventing early childhood diarrhoea. Int J Nurs Pract. 2017;23:e12524. https://doi.org/10.1111/ijn.12524 
6. Bandura A. On the functional properties of perceived self-efficacy revisited. J Manage. 2012;38(1):9-44. https://doi. org/10.1177/0149206311410606

7. Gomes ALA, Joventino ES, Lima KF, Dodt RCM, Almeida PC, Ximenes LB. Validation and reliability of the scale Self-efficacy and their child's level of asthma control. Rev Bras Enferm. 2018;71(2):406-12. https://doi.org/10.1590/0034-7167-2016-0528

8. Gomes ALA, Lime KF, Mendes ERR, Joventino ES, Martins MC, Almeida PC, et al. Association of self-efficacy of parents/caregivers with childhood asthma control parameters. Rev Esc Enferm USP. 2017;51:e03282. Available from: 10.1590/S1980-220X2017008003282

9. Lima KF. Cartilha educativa para a promoção da autoeficácia de pais e/ou cuidadores no controle e manejo da asma em crianças: validação de conteúdo [Dissertação]. [Fortaleza (CE)], Universidade Federal do Ceará; 2018. 176 p.

10. Doak CC, Doak LG, Root JH. Teaching patients with low literacy skills. Philadelphia: J.B. Lippincott; 1996. 212 p.

11. Ministério da Saúde (BR), Conselho Nacional de Saúde. Resolução n466, de 12 de dezembro de 2012. Estabelece critérios sobre pesquisa envolvendo seres humanos. Brasília: Diário Oficial União; 2013.

12. Fehring RJ. Validating diagnostic labels: standardized methodology. In: Hurley ME, (Ed.). Classification of nursing diagnoses: proceedings of the sixth conference. St. Louis, MO: Mosby; 1986. p. 183-90.

13. Moreira MF, Nóbrega MML, Silva MIT. Comunicação escrita: contribuição para a elaboração de material educativo em saúde. Rev Bras Enferm. 2003;56(2):184-8. https://doi.org/10.1590/\$0034-71672003000200015

14. US Health Centers for Disease Control and Prevention. Strategic and proactive communication branch simply put: a guide for creating easyto- understand materials. Third Edition: Atlanta; 2009. Georgia.

15. Deatrick D, Aalberg J, Cawley J. A guide to creating and evaluating patient materials: guidelines for effective print communication [Internet]. 2010 [cited 2019 May 10]. Available from: https://mainehealth.org/healthcare-professionals/education-and-training/health-literacy/ tools-for-health-literacy

16. Federal Plain Language Guidelines. The Plain Language Action and Information Network [Internet] 2011 [cited May 10]. Available from: http://www.plainlanguage.gov/howto/guidelines/FederalPLGuidelines/FederalPLGuidelines.pdf

17. Global Initiative For Asthma (GINA). Global Strategy for Asthma Management and Prevention 2018 [Internet]. 2018 [cited 2020 Mar 05]. Available from: http://www. ginaasthma.com

18. Sociedade Brasileira de Pneumologia e Tisiologia (SBPT). Diretrizes da Sociedade Brasileira de Pneumologia e Tisiologia para o manejo da asma. J Bras Pneumol [Internet]. 2012 [cited 2020 Feb 5];38(1):1-46. Available from: https://www.sbp.com.br/fileadmin/user_upload/pdfs/ Diretrizes_Sociedade_Brasileira_Pneumologia-Tisiologia_Manejo_Asma-2012.pdf

19. Ministério da Saúde (BR). Secretaria de Atenção à Saúde. Portaria n 1317, de 25 de novembro de 2013. Aprova o Protocolo Clínico e Diretrizes Terapêuticas da Asma. Brasília: Diário Oficial da União; 2013.

20. Norwood SL. Research strategies for advanced practice nurses. Upper Saddle River, NJ: Prentice Hall Health; 2006.499 p.

21. Polit DF, Beck CT. The content validity index: are you sure you know what's being reported? critique and recommendations. Res Nurs Health [Internet]. 2006 [cited 2017 Mar 24];29(5):489-97. https://doi.org/10.1002 / nur.20147

22. Fernandes MVL, Lacerda RA, Hallage NM. Construção e validação de indicadores de avaliação de práticas de controle e prevenção de infecção do trato urinário associada a cateter. Acta Paul Enferm. 2006;19(2):174-89. https://doi.org/10.1590/S0103-21002006000200009

23. Sabino LMM, Ferreira AMV, Mendes ERR, Joventino ES, Gubert FA, Penha JC, et al .Validation of primer for promoting maternal self-efficacy in preventing childhood diarrhea. Rev Bras Enferm. 2018;71(3):1412-9. https://doi.org/10.1590/0034-7167-2017-0341

24. Palmo E, Gallucci M, Cipriani F, Bertelli L, Giannetti A, Ricci G. Asthma and food allergy: which risks? Medicina (Kaunas). $2019 ; 55(9): 509$. https://doi.org/10.3390/medicina55090509

25. Kansen HM, Le TM, Uiterwaal C, van Ewijk BE, Balemans W, Gorissen D, et al. Prevalence and predictors of uncontrolled asthma in children referred for asthma and other atopic diseases. J Asthma Allergy. 2020;13:67-75. https://doi.org/10.2147/JAA.S231907

26. D'Amato G, Holgate ST, Pawankar R, Ledford DK, Cecchi L, Al-Ahmad M, et al. Meteorological conditions, climate change, new emerging factors, and asthma and related allergic disorders: a statement of the World Allergy Organization. World Allergy Organ J. 2015;8(1):1-52. https://doi.org/10.1186/s40413-015-0073-0

27. González-Conde VM, Pérez-Fernández V, Ruiz-Esteban C, Valverde-Molina J. Impact of self-efficacy on the quality of life of children with asthma and their caregivers. Arch Bronconeumol. 2019;55(4):189-94. https://doi.org/10.1016/j.arbr.2019.02.004

28. Gruber KJ, McKee-Huger B, Richard A, Byerly B, Raczkowski JL, Wall TC. Removing asthma triggers and improving children's health: The Asthma Partnership Demonstration project. Ann Allerg Asthma Im. 2016;116(5):408-14. https://doi.org/10.1016/j.anai.2016.03.025

29. Yin HS, Gupta RS, Tomopoulos S, Mendelsohn AL, Egan M, Van Schaick L, et al. A low-literacy asthma action plan to improve provider asthma counseling: a randomized study. Pediatrics. 2016;137(1); e20150468. https://doi.org/10.1542/peds.2015-0468

30. Comaru T, Pitrez PM, Friedrich FO, Silveira VD, Pinto LA. Free asthma medications reduces hospital admissions in Brazil. Respir Med. 2016;121:21-5. https://doi.org/10.1016/j.rmed.2016.10.008

31. Shor D, Rizzo JA, Medeiros D, Dela Bianca AC, Silva AR, Nunes C, et al. Home-made spacer as an auxiliary device in administration of beclomethasone via pressurized metered dose inhaler for asthma control. A randomized controlled pragmatic trial. Respir. Med. 2017; 126: 52-58. https://doi.org/10.1016/j.rmed.2017.03.017 
32. Muller I, Kirby S, Yardley L. Understanding patient experiences of self-managing chronic dizziness: a qualitative study of booklet-based vestibular rehabilitation, with or without remote support. BMJ Open. 2015;5(5):e007680. https://doi.org/10.1136/bmjopen-2015-007680

33. Benevides JL, Coutinho JFV, Pascoal LC, Joventino ES, Martins MC, Gubert FA, et al. Development and validation of educational technology for venous ulcer care. Rev Esc Enferm USP. 2016;50(2):306-12. https://doi.org/10.1590/S0080-623420160000200018 